University of Nebraska - Lincoln

DigitalCommons@University of Nebraska - Lincoln

\title{
Pyrolysis of switchgrass (Panicum virgatum) harvested at several stages of maturity
}

\author{
A. A. Boateng \\ USDA-ARS, aboateng@errc.ars.usda.gov \\ K. B. Hicks \\ USDA-ARS \\ Kenneth P. Vogel \\ University of Nebraska-Lincoln, kvogel1@unl.edu
}

Follow this and additional works at: https://digitalcommons.unl.edu/usdaarsfacpub

Boateng, A. A.; Hicks, K. B.; and Vogel, Kenneth P., "Pyrolysis of switchgrass (Panicum virgatum) harvested at several stages of maturity" (2006). Publications from USDA-ARS / UNL Faculty. 1946. https://digitalcommons.unl.edu/usdaarsfacpub/1946

This Article is brought to you for free and open access by the U.S. Department of Agriculture: Agricultural Research Service, Lincoln, Nebraska at DigitalCommons@University of Nebraska - Lincoln. It has been accepted for inclusion in Publications from USDA-ARS / UNL Faculty by an authorized administrator of DigitalCommons@University of Nebraska - Lincoln. 


\title{
Pyrolysis of switchgrass (Panicum virgatum) harvested at several stages of maturity ${ }^{\text {is }}$
}

\author{
A.A. Boateng ${ }^{\mathrm{a}, *}$, K.B. Hicks ${ }^{\mathrm{a}}$, K.P. Vogel ${ }^{\mathrm{b}}$ \\ ${ }^{a}$ U.S. Department of Agriculture, Agricultural Research Service, Eastern Regional Research Center, \\ 600 E. Mermaid Lane, Wyndmoor, PA 19038, USA \\ ${ }^{\mathrm{b}}$ U.S. Department of Agriculture, Agricultural Research Service, 344 Keim Hall, University of Nebraska, \\ PO Box 83093, Lincoln, NE 68583-0937, USA
}

Received 8 November 2004; accepted 1 March 2005

Available online 11 May 2005

\begin{abstract}
The pyrolysis of switchgrass (Panicum virgatum) of the cultivar, "Cave-in-Rock" harvested at three stages of physiological maturity was studied in a PY-GC/MS system at the $600-1050{ }^{\circ} \mathrm{C}$ temperature range. Under these conditions, the decomposition was complete within $20 \mathrm{~s}$ yielding char, and two sets of pyrolysis gas, condensable and non-condensable. The former consisted of acetaldehyde $\left(\mathrm{CH}_{3} \mathrm{CHO}\right)$, acetic acid $\left(\mathrm{CH}_{3} \mathrm{COOH}\right)$ and higher molecular weight compounds possibly from the hydroxyl group and from the methoxy groups of the cell wall components. The non-condensable gases were mainly $\mathrm{CO}, \mathrm{CO}_{2}$ and $\mathrm{C}_{1}-\mathrm{C}_{3}$ hydrocarbons. For these, there was a $900{ }^{\circ} \mathrm{C}$ temperature boundary where dramatic change occurred in their evolution rates. Below this temperature, $\mathrm{CO}_{2}$ decreased but $\mathrm{CO}$ and the $\mathrm{C}_{1}-\mathrm{C}_{3}$ hydrocarbons increased almost linearly with temperature. Above this temperature boundary, the hydrocarbons leveled off but there was a rapid rise in $\mathrm{CO}$ and $\mathrm{CO}_{2}$ evolution at a constant $\mathrm{CO} / \mathrm{CO}_{2}$ ratio. These suggest the appearance of secondary or tertiary pyrolysis reactions involving rearrangement and release of $\mathrm{CO}$ and hydrocarbons prior to this temperature boundary and the release of $\mathrm{CO}$ and $\mathrm{CO}_{2}$ from the tightly bond oxygen functionalities including $\mathrm{C}-\mathrm{C}$ bonds thereafter. At $<750{ }^{\circ} \mathrm{C}$, there were modest increases in condensable gas yield and decrease in non-condensable gas due to differences in plant maturity at harvest. However, the effect of switchgrass physiological maturity on gas yield was statistically insignificant at high temperatures. The energy content of the non-condensable gas measured was about $68 \%$ of the gross energy content of the biomass for the early harvest crop and $80 \%$ for the mature crop. The activation energy for the decomposition, estimated assuming first order reaction kinetics, showed a linear increase with plant physiological maturity. The results demonstrate that physiological maturity at harvest of switchgrass biomass can result in different concentrations of pyrolysis products at different temperatures. These results also demonstrate the need for additional research with a broader array of herbaceous biomass materials to develop a better understanding of the synergies of crop cultivation, harvesting and processing of dedicated herbaceous biomass energy crops during their thermochemical conversion.
\end{abstract}

(C) 2005 Elsevier B.V. All rights reserved.

Keywords: Switchgrass; Pyrolysis; Thermochemical conversion; Bioenergy crop conversion

\section{Introduction}

To decrease US dependence on imported petroleum and to ensure long-term sustainability in our economy and the

\footnotetext{
Mention of trade names or commercial products in this article is solely for the purpose of providing specific information and does not imply recommendation or endorsement by the U.S. Department of Agriculture.

* Corresponding author. Tel.: +1 215233 6493; fax: +1 2152336406

E-mail address: aboateng@errc.ars.usda.gov (A.A. Boateng).
}

environment, government programs are currently in place under the biomass initiative platform to conduct R\&D that supports the bioenergy concept. A long-term goal of these programs is to invest in the development of biorefineries as an alternative to petroleum refineries (http://www.eere. energy.gov/biomass/integrated_biorefineries.html). This is intended to substitute renewable biomass feedstock for petroleum based resources and produce a wide array of fuels and chemicals currently only possible with fossil-fuel resources. Although the goal is achievable, the challenges 
are many, including what conversion technologies to pursue, what feedstock to employ and even what products to make that will be economically competitive [1]. To this end, several R\&D programs have been instituted within the U.S. Department of Energy (DOE) and the U.S. Department of Agriculture (USDA) encompassing various milestones. These include the feedstock interface, sugar, thermochemical and products platforms.

Because of the immense interest in developing alternative liquid fuels, considerable research and development efforts have been invested in recent years to convert crop residues, herbaceous and woody crops, dedicated energy crops and other types of biomass identified under the feedstock platform into ethanol via the sugar platform. It is evident that despite continued progress, the prospect of developing cost effective processes for conversion of biomass into ethanol in the next 10-20 years poses a big challenge [2]. Part of the problem is attributed to the large variability in biomass composition, which may require different enzymes or chemical processes for hydrolysis of the biomass polysaccharides into fermentable sugars, and then the development and use of recombinant organisms that can ferment the $\mathrm{C}_{5}$ and $\mathrm{C}_{6}$ sugars produced. On the other hand, others have shown that thermochemical conversion of biomass may be a more practical and viable conversion option in the near- and mid-term basis [3]. Thermal, steam and partial gasification technologies currently under development around the world have demonstrated that gasification (including catalytic gasification coupled with steam-reform that takes advantage of the water-gas shift reaction) holds most promise because of increased hydrogen yield $[4,5]$. Hence, rather than attempting to pretreat, hydrolyze and ferment complex biomass materials into ethanol under the sugar platform, in some instances, and in the near term, the thermochemical platform may be an attractive alternative approach for biomass conversion into renewable energy, i.e. through pyrolytic and gasification processes. Additionally, colocating these systems with ethanol plants may yield operational and economic synergies. This can be especially attractive when the fibrous byproducts generated from the ethanol process have little or no nutritional value, when the energy is renewable, and when other valuable coproducts, e.g. activated charcoal, fertilizer enhancers, etc. can be developed [3].

Biomass pyrolysis can yield char, pyrolytic oils and gaseous products comprising $\mathrm{H}_{2}, \mathrm{CO}, \mathrm{CO}_{2}$ and lower molecular weight hydrocarbon gases. A gas mixture rich in $\mathrm{CO}$ and $\mathrm{H}_{2}$ (syngas) can itself be converted to mixed alcohols (methanol, ethanol, etc.) via processes similar to the Fischer Tropsch process [6,7]. Furthermore, pyrolytic oils can undergo cracking to lower molecular weight gases and can also be steam-reformed to $\mathrm{CO}$ and $\mathrm{H}_{2}$. Syngas can also be used as a fuel to provide process heat, steam and power generation within the plant. Although some economic analyses [8] have shown that direct-firing, co-firing, gasification and pyrolysis of biomass may, as stand-alone unit operations, not be competitive with existing fossil-fuel power generation facilities, developing improved gasification processes might. Therefore, ideas to improve the economics associated with thermochemical conversion have included, for example, developing compact, mobile equipment systems to do the conversion, especially if such mobile systems can eliminate transportation costs for biomass to a distant centralized facility. Another proposed approach to achieving efficiency is to carry out the gasification in the field to produce pyrolytic oil as an intermediate product which can be easily stored, transported and hauled to a central area for further reforming processes.

Many system analyses including that by Milne et al. [3] have shown that irrespective of unfavorable economics associated with biomass steam-reform as compared to natural gas steam-reforming, the economics improve for lower cost biomass such as certain herbaceous and woody crop species [9] identified as energy crops under the National energy roadmap program (http://www.bioproducts-bioenergy.gov/pdf/Ag_Roadmap.pdf). Developing a significant national capacity to utilize perennial forage crops as biofuels could not only reduce foreign fuel dependency and environmental hazards but could also benefit the agricultural economy by providing new sources of income for farmers [10]. Hence, in 1991, a decision was made by the biomass feedstock development program to focus on switchgrass (Panicum virgatum L.), a high yielding perennial grass species which combines excellent conservation attributes and good compatibility with conventional farming practices. Since then research including management field trials, breeding, tissue culture and physiological/ genetic and other activities has been conducted to improve the productivity of switchgrass grown as an energy crop [11,12]. Switchgrass is an erect, warm-season perennial which was native to most of North America except for the areas west of the Rocky Mountains and north of $55^{\circ} \mathrm{N}$. latitude [13]. It is a $\mathrm{C}_{4}$ species and has the anatomical and physiological characteristics of $\mathrm{C}_{4}$ grasses. Switchgrass has been seeded in pastures and rangeland in pure stands and mixtures in the Great Plains for more than 60 years and in the past 20 years, it has become increasingly important as a pasture grass in the central and eastern USA [13].

In this submission, switchgrass samples developed specifically for biomass conversion research were evaluated for their pyrolysis characteristics [14]. The switchgrass samples were produced using management conditions optimal for production of switchgrass as a biomass energy crop in the Midwest, USA and were harvested at three distinct physiological stages of maturity representative of potential harvest stages $[13,14]$.

\section{Experimental}

Flash pyrolysis experiments were carried out in a Pyroprobe (PY) 2000 (CDS Analytical, Oxford, PA). It 
comprises a quartz tube, which is heated by a platinum filament, 2-3 $\mathrm{mm}$ diameter and $1 \mathrm{~cm}$ length and capable of maintaining up to $1200{ }^{\circ} \mathrm{C}$ temperature. The interface temperature was set at $300{ }^{\circ} \mathrm{C}$. The pyrolyzer is interfaced to a HP 6890N gas chromatograph (GC) and HP 5973 mass spectrometer (Agilent Technologies). The pyroprobe/chromatograph/mass-spectrometer (PY-GC/MS) was used for the identification of the variety of compounds formed during flash pyrolysis. The GC analysis was performed using a fused silica capillary column, CP-PoraBOND Q, $25 \mathrm{~m} \times 0.25 \mathrm{~mm}$ (Varian, Palo Alto, CA) with the following program: $3 \mathrm{~min}$ at $35^{\circ} \mathrm{C}$ then ramped at $5{ }^{\circ} \mathrm{C} / \mathrm{min}$ up to $150{ }^{\circ} \mathrm{C}$ followed by $10^{\circ} \mathrm{C} / \mathrm{min}$ up to $250{ }^{\circ} \mathrm{C}$ for a total time of $36 \mathrm{~min}$. MS detection was carried out under electron impact (EI) ionization conditions in full scan from $\mathrm{m} / \mathrm{z} 2-80$ with a threshold at 300 . This enabled the detection of the yields of the major products of primary and secondary pyrolysis reactions as functions of temperature and heating conditions. Calibration curves were done using a standard gas mixture comprising $\mathrm{CO}, \mathrm{CO}_{2}, \mathrm{CH}_{4}, \mathrm{C}_{2} \mathrm{H}_{4}, \mathrm{C}_{2} \mathrm{H}_{6}, \mathrm{C}_{3} \mathrm{H}_{8}$ and $\mathrm{C}_{4} \mathrm{H}_{10}$ in helium (custom-mixed by Scott Specialty Gases, Plumsteadville, PA) to quantify the yields of the noncondensable gases as percentage of the initial biomass mass. Char yield was determined gravimetrically. All other gases, comprising the condensable gases such as pyrolytic oil vapors and also the non-condensable ones that were not calibrated were estimated as "tar." This, including hydrocarbon gases greater than $\mathrm{C} 4$ and hydrogen, was determined as the difference between the biomass and the measured gas plus the remaining char. Hydrogen could not be detected due to the lack of a thermal conductivity detector (TCD) and was assumed as part of the non-calibrated gas "tar" yield.

The switchgrass samples labeled MPV1, MPV2 and MPV3 samples were produced specifically for research on conversion technologies for production of ethanol and pyrolysis products and their characteristics and composition are fully described by Dien et al. [14]. In brief, the samples are from established plots of the cultivar 'Cave-in-Rock' that were fertilized with annual applications of $120 \mathrm{~kg} \mathrm{~N} / \mathrm{ha}$. They were harvested at three different physiological stages of maturity. MPV1 (Midwest P. virgatum sample 1) was produced from a regrowth harvest that was harvested when the regrowth was at the E3 stage of maturity [15]. At this stage of maturity, the biomass is pre-boot and is primarily leaf blades, sheaths and partially elongated stems. A farmer would harvest switchgrass for high quality hay at this stage of maturity because of its high digestibility [13]. MPV2 and MPV3 were harvested at the R4 and post-frost senescence stages (post-S5 stage) of maturity from total season growth, respectively. Switchgrass biomass tissue at the R4 stage consists of plants that have reached their maximum height and yield and have flowered. Post-frost plants had fully matured and set seed and represent biomass tissue that has become fully mature and lignified. MPV2 and MPV3 represent the two main potential harvest stages for optimizing biomass yield [13]. The harvesting height for all samples was $10 \mathrm{~cm}$ [14]. After each harvest, the harvested material was air dried on a greenhouse bench. The dried material was then ground with a Wiley mill through a $2 \mathrm{~mm}$ screen. The ground material was thoroughly mixed and stored in plastic 5 gallon buckets with sealed lids [14]. Pulverized switchgrass samples, $90 \%$ passing $500 \mu \mathrm{m}$, were used for the pyrolysis experiments. The average weight of the charge was about $1 \mathrm{mg}$ and occupied about $1-1.5 \mathrm{~mm}$ in height in the quartz tube pyrolyzer over packed quartz wool. The experimental sample preparation procedure was consistent with published works [16,17], which have reported that samples weighing less than $2 \mathrm{mg}$ give no significant changes in hydrocarbon yield.

Although there is little or no heat resistance to the sample itself given the small volume to surface area ratio, samples in the pyroprobe do not follow the heating profile of the platinum wire due to the heat capacity of the quartz tube holding them. However, samples do not cool instantaneously which thereby helps maintain the set-point temperature for quite sometime when the power is turned off. Caballero et al. [16] performed heat balance calculations for the heating and cooling of lignin samples in a CDS Analytical's Pyroprobe 1000 and found the heat transfer coefficient for heating to be $680 \mathrm{~W} / \mathrm{m}^{2} \mathrm{~K}$ and that for the cooling to be $24 \mathrm{~W} / \mathrm{m}^{2} \mathrm{~K}$. With these coefficients, they estimated about $200{ }^{\circ} \mathrm{C}$ temperature lag at about $2.5 \mathrm{~s}$ for a $600{ }^{\circ} \mathrm{C}$ pyrolysis set-point temperature. In the CDS Pyroprobe 2000 used in the present experiments, heating rate selection is carried out electronically by a computer as against electrical resistors in the case of the older, e.g. CDS 100 series. This allows access to a selection of a wider range of heating rates and time to reach the set-point temperature. According to CDS Analytical, the set-point temperature controls the filament temperature so the time that is selected is the time at which the set-point temperature is held at before cooling begins. Experiments carried out by CDS Analytical [18] have shown that the temperature lag between a typical sample in the quartz tube and the filament of the Pyroprobe 2000 is about $100{ }^{\circ} \mathrm{C}$ for a $700{ }^{\circ} \mathrm{C}$ filament temperature.

In view of this, therefore, flash pyrolysis was carried out at set-point temperatures of $600,750,900$ and $1050{ }^{\circ} \mathrm{C}$ for several retention times of $1,3,5,10$ and $20 \mathrm{~s}$. The extended temperature was to ensure that greater than $400{ }^{\circ} \mathrm{C}$, classified as the temperature delineation where secondary pyrolysis begins, was assured. Within $10 \mathrm{~s}$ devolatilization was virtually complete but $20 \mathrm{~s}$ was employed as the final devolatilization time to ensure that no extra gas remained in the pyrolyzer.

\section{Results and discussion}

Our goal was to determine if physiological maturity of switchgrass biomass had an effect on pyrolysis yield. The complete compositional profiles of the samples used in this study are reported by Dien et al. [14]. There were major 
differences as expected among samples for lignin, ash, soluble and cell wall carbohydrates. As an example, Klason lignin concentrations were 133,154 and $173 \mathrm{~g} / \mathrm{kg}$ dry matter for MPV1, MPV2 and MPV3, respectively [14]. Sanderson and Wolf [19] have shown that later harvest switchgrass leads to lower ash content. In direct combustion, mature switchgrass, and for that matter low ash content fuel, may lead to less slagging and hence reduced fouling of heat transfer equipment. During conversion by gasification/ pyrolysis, higher lignin content often associated with maturity may result in a high calorific value gas. The latter was the focus of this investigation.

Teng and Wei [20] interpreted differential thermogravimetric (DTG) data on rice hulls and asserted that the hemicellulose decomposes first, followed by cellulose and then lignin. They found the activation energy for the decomposition reaction, established by assuming first order reaction kinetics, to be greatest for cellulose then hemicellulose with activation energy for lignin being the lowest of the three. Caballero et al. [16] have reported that $\mathrm{CH}_{4}$ and $\mathrm{C}_{2} \mathrm{H}_{6}$ yields increase with temperature similar to cellulose and lignin but $\mathrm{CO}_{2}$ and $\mathrm{H}_{2} \mathrm{O}$ increases are greater for cellulose than for lignin. Fushimi et al. [21] also have observed that the onset of cellulose pyrolysis is $250{ }^{\circ} \mathrm{C}$ beginning with the formation of cellulose intermediates followed by $\mathrm{CO}_{2}$ evolution after which the evolution of $\mathrm{CO}_{2}$, $\mathrm{CO}$ and $\mathrm{H}_{2}$ proceed with $\mathrm{CO}$ and $\mathrm{H}_{2}$ increasing rapidly and peaking at about $427{ }^{\circ} \mathrm{C}(700 \mathrm{~K})$. They have also reported that over $80 \%$ of the cellulose structure would have been depolymerized at this temperature. However, lignin decomposition occurs slowly over a broader temperature range than cellulose and hemicellulose. Unlike cellulose, CO evolution from lignin is reported to begin at $227^{\circ} \mathrm{C}$ followed by $\mathrm{CO}$ and $\mathrm{CH}_{4}$ instead of $\mathrm{CO}$ and $\mathrm{H}_{2}$ and increases gradually up to about $500{ }^{\circ} \mathrm{C}$ before the onset of $\mathrm{H}_{2}$ evolution. All of these prior observations have led to the socalled $400{ }^{\circ} \mathrm{C}$ temperature delineation between primary and secondary pyrolysis reactions [22].

Fig. 1 presents a snapshot of a larger body of results from the PY-GC/MS analysis. These chromatograms show the evolution of two sets of pyrolysis gas products, the condensable gaseous product which can be condensed to form pyrolytic oils (bio-oil), and the non-condensable gas (syngas). The components of the former that were detected with the GC method we employed and mentioned earlier consisted of water $\left(\mathrm{H}_{2} \mathrm{O}\right)$, acetaldehyde $\left(\mathrm{CH}_{3} \mathrm{CHO}\right)$, acetic acid $\left(\mathrm{CH}_{3} \mathrm{COOH}\right)$ and 1-hydroxy-2-propanone $\left(\mathrm{C}_{3} \mathrm{H}_{6} \mathrm{O}_{2}\right)$ compounds probably from the hydroxyl group and from the methoxy groups of the lignin component of biomass. It has been reported [16] that these condensable gases do not change beyond $550{ }^{\circ} \mathrm{C}$ which indicates that their evolution might have peaked prior to the initial $600{ }^{\circ} \mathrm{C}$ temperature we studied. The non-condensable gases detected were mainly $\mathrm{CO}, \mathrm{CO}_{2}$ and $\mathrm{C}_{1}-\mathrm{C}_{3}$ hydrocarbons as have been reported by others for biomass decomposition [16,20]. In Table 1, we present the full range of the yields we measured for all

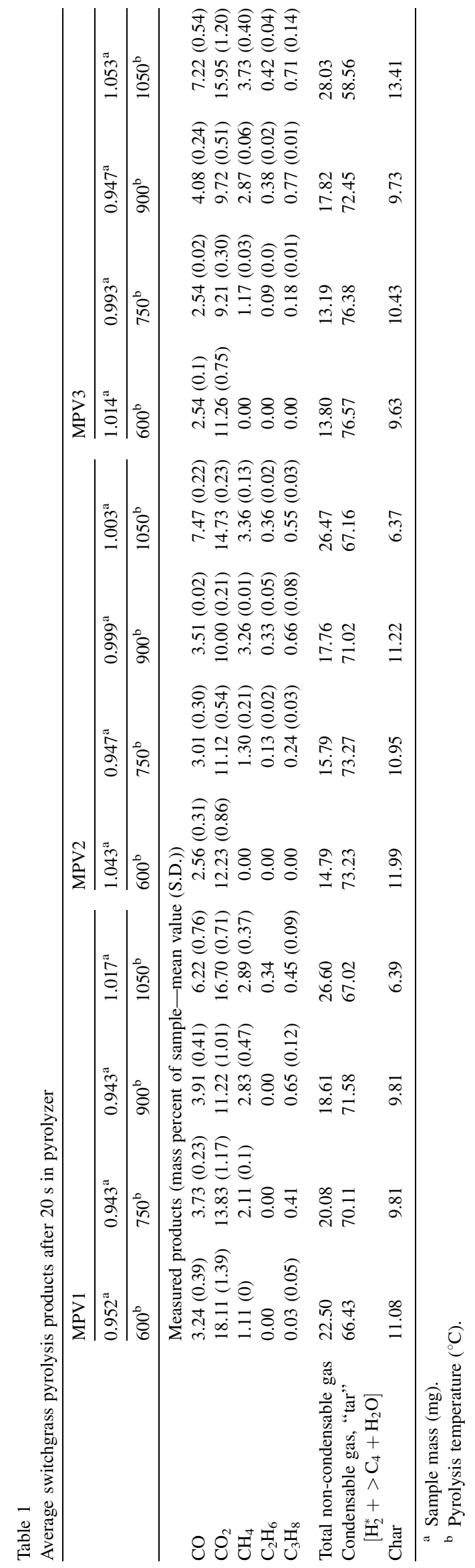



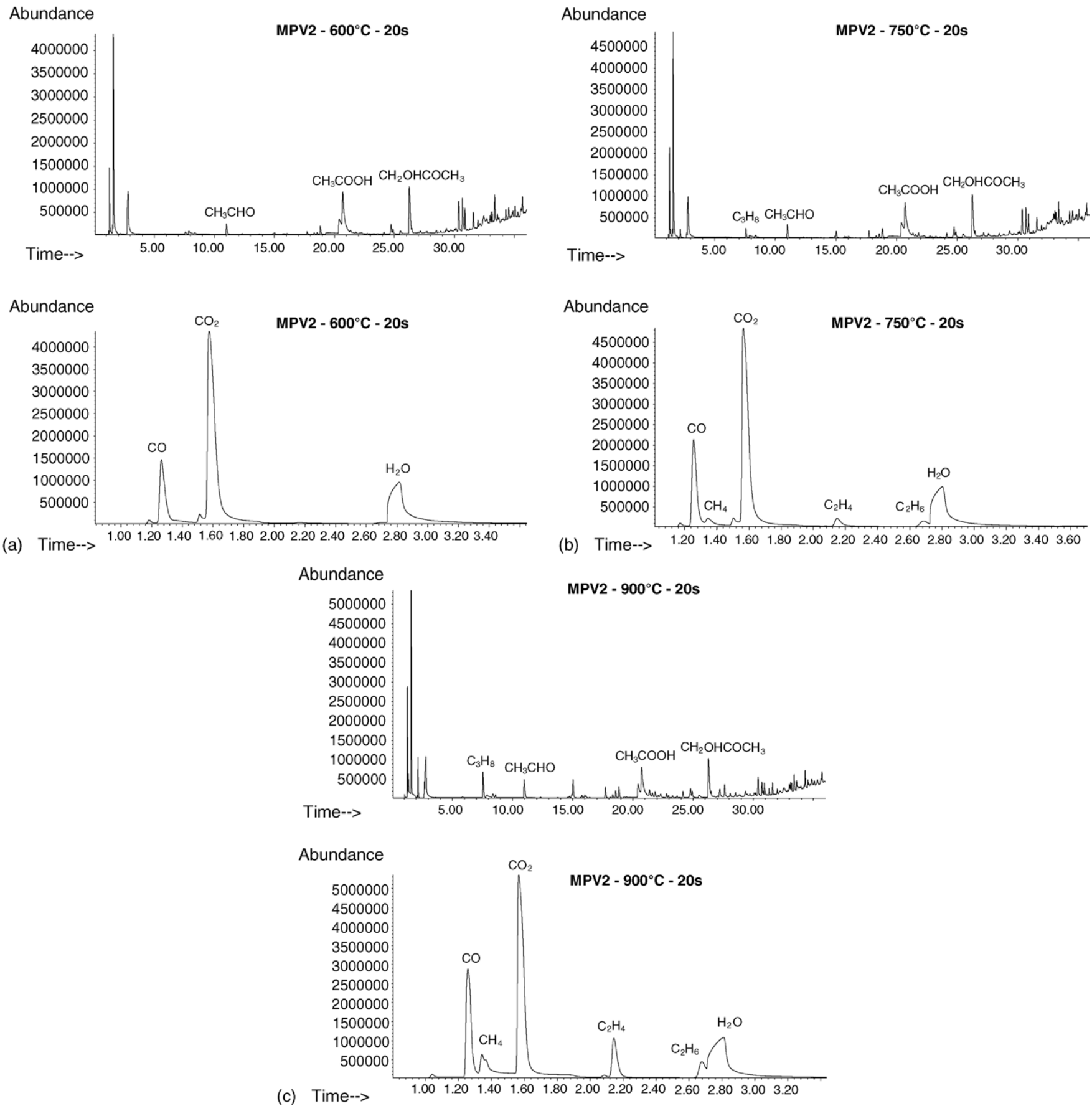

Fig. 1. (a) Chromatograms of switchgrass pyrolysis at $600{ }^{\circ} \mathrm{C}$; (b) chromatograms of switchgrass pyrolysis at $750{ }^{\circ} \mathrm{C}$ showing the onset of lightweight hydrocarbons; (c) chromatographs of switchgrass pyrolysis at $900{ }^{\circ} \mathrm{C}$.

samples and all temperatures. The $\mathrm{CO}$ produced ranged from $2.55 \%$ at $600{ }^{\circ} \mathrm{C}$ to $7.47 \%$ at $1050{ }^{\circ} \mathrm{C}$. $\mathrm{CO}_{2}$ yield ranged from 9.2 to $18.11 \%, \mathrm{CH}_{4}$ ranged from 0 to $3.73 \%, \mathrm{C}_{2} \mathrm{H}_{6}$ ranged from 0 to $0.42 \%$ and $\mathrm{C}_{3} \mathrm{H}_{8}$ ranged from 0 to $0.77 \%$ for all samples. Butane was not detected although it was one of the gases we calibrated. The sum of the yield of the noncondensable gases we quantified, i.e. $\mathrm{CO}_{2}, \mathrm{CO}, \mathrm{CH}_{4}, \mathrm{C}_{2} \mathrm{H}_{6}$ and $\mathrm{C}_{3} \mathrm{H}_{8}$, ranged between $13.2-28.03 \%$. Char yield ranged from 6.37 to $13.4 \%$. The condensable gas "tar" yield, estimated by difference, ranged from 58.55 to $76.57 \%$.
These results are consistent with published work on several biomass species pyrolyzed within the same temperature range $[16,23]$ and under similar experimental conditions.

\subsection{Temperature effects}

The temperature effect on the non-condensable gas yields is shown in Fig. 2. The effect on char yield is shown in Fig. 3. There seems to be a $900{ }^{\circ} \mathrm{C}$ temperature boundary where noticeable change occurs in the rate of evolution of 


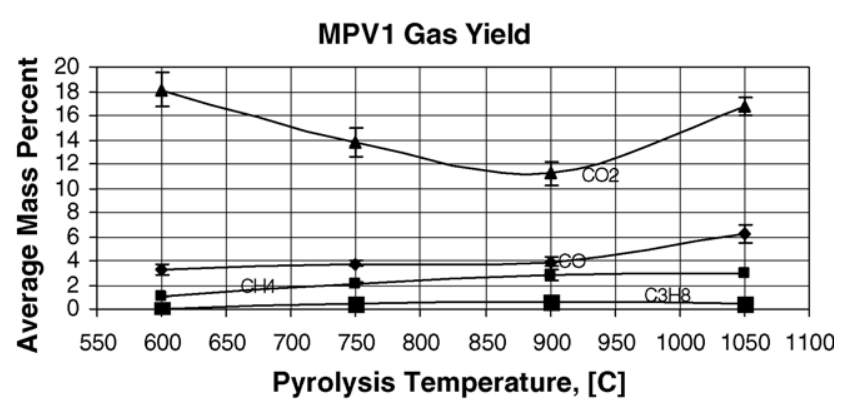

MPV2 Gas Yield

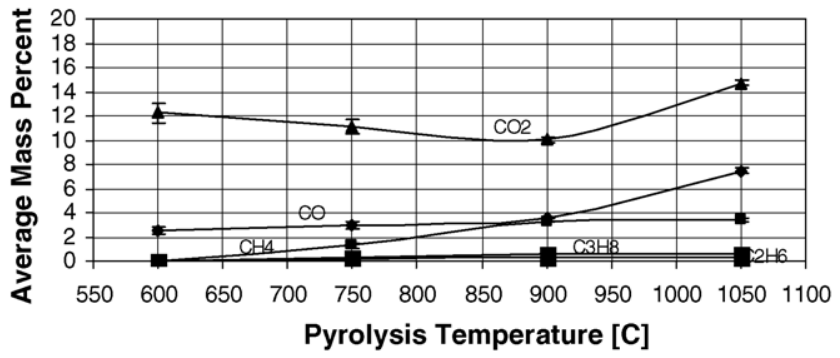

MPV3 Gas Yield

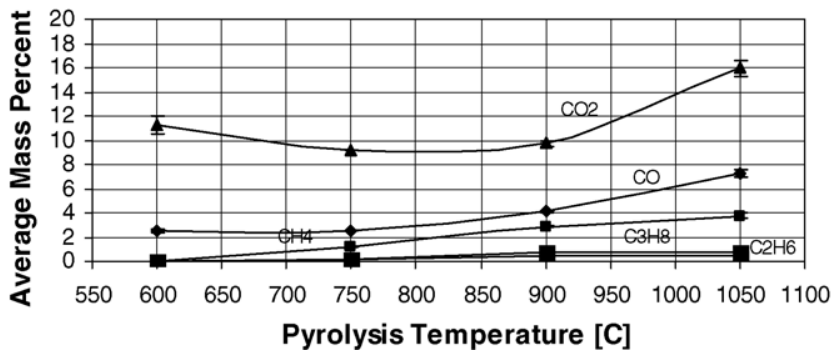

Fig. 2. Gas yield as function of pyrolysis temperature for the three switchgrass samples pyrolyzed. MPV1 (E1); MPV2 (R4); MPV3 (S5).

the non-condensable gases. For all samples, $\mathrm{CO}_{2}$ decreased almost linearly with temperature up to $900{ }^{\circ} \mathrm{C}$ and then increased thereafter. $\mathrm{CO}$ increased gradually up to $900{ }^{\circ} \mathrm{C}$ followed by a rapid rise but at the same rate as the $\mathrm{CO}_{2}$, i.e. at constant $\mathrm{CO} / \mathrm{CO}_{2}$ ratio. The $\mathrm{C}_{1}-\mathrm{C}_{3}$ hydrocarbons also increased with temperature up to $900{ }^{\circ} \mathrm{C}$ and leveled off thereafter. The char remaining after pyrolysis is also temperature dependent, however, the large scatter in the data, due primarily to difficulties in measuring tiny samples of char, confounds any meaningful conclusions on the

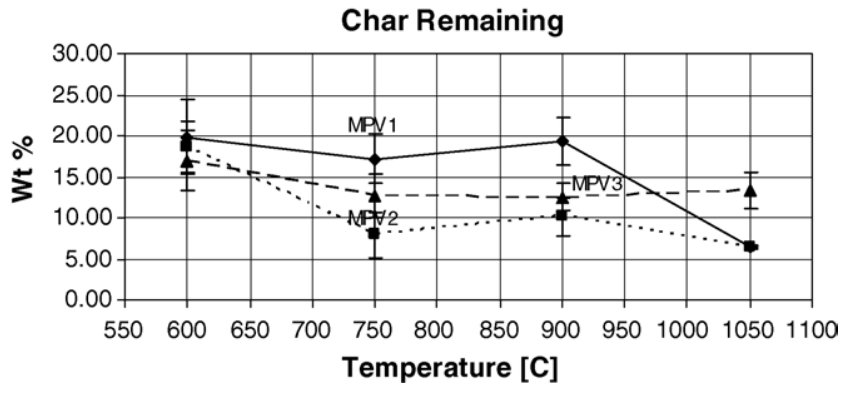

Fig. 3. Average char remaining for all times as function of pyrolysis temperature. affects of temperature or plant maturity on char yield. Although hydrogen was not measured, its yield and evolution pattern are known to be typically similar to that of $\mathrm{CO}$ on mole basis [24] and increases with temperature. Consistent with the analyses provided by others on biomass pyrolysis, it appears that at the starting $600{ }^{\circ} \mathrm{C}$ temperature, condensable gases from the lignin might have peaked, as has most of the $\mathrm{CO}_{2}$ production from the carboxyl groups of the cell wall carbohydrate (cellulose and hemicellulose) decomposition. Beyond $600{ }^{\circ} \mathrm{C}$, gradual decomposition of the lignin intermediates proceeds with the evolution of $\mathrm{CO}$. At the same temperature occurs the onset of secondary reactions involving the pyrolysis of the remaining lignin intermediates, char and the condensable gases to further yield $\mathrm{CO}$ and $\mathrm{C}_{1}-\mathrm{C}_{3}$ hydrocarbons. Avni et al. [25] carried out several lignin pyrolysis studies using FT-IR at temperatures ranging between 150 and $900{ }^{\circ} \mathrm{C}$. The pyrolysis model that fitted their data could simulate the evolution of tar fragments and competitive cracking of substituted functional groups and ring clusters, shown in the lignin polymer, to form light molecular weight hydrocarbon. They also reported that at temperatures equivalent to the mid-range of the study reported here, decomposition of the substituted groups and aliphatic structures occurred resulting in the release of $\mathrm{CO}_{2}$ from the carboxyl groups, $\mathrm{H}_{2} \mathrm{O}$ from the hydroxyl groups, $\mathrm{CO}$ from the weakly bound oxygen groups such as aldehyde groups and hydrocarbon gases from the aliphatic and the methoxy groups. By $900{ }^{\circ} \mathrm{C}$, the light hydrocarbon gases we measured had leveled off (Fig. 2), but the sudden rise in $\mathrm{CO}$ and $\mathrm{CO}_{2}$ beyond this temperature boundary occurs due probably to tertiary reactions involving the thermal degradation of stronger bonds perhaps of the pyrolytic vapor compounds consistent with the observation by Ralph and Hatfield [26]. They have shown that at higher temperatures, breakage and rearrangement of the aromatic rings occurred thereby permitting the evolution of aromatic hydrogen and additional $\mathrm{CO}$ from the tightly bound oxygen functionalities such as ethers and phenols and other $\mathrm{C}-\mathrm{C}$ links.

\subsection{Effect of physiological maturity}

Figs. 4-7 show the relationships between pyrolysis gas yield and physiological stage of maturity of the switchgrass biomass. There appears to be a modest increase in the condensable gas from vegetative through the fully senescence stages of maturity (MPV1-MPV3) at 600 and $750{ }^{\circ} \mathrm{C}$ (Fig. 4). At 900 and $1050{ }^{\circ} \mathrm{C}$, yields of condensable gases appear to be constant or decline with maturity. The opposite can be said about the non-condensable gases however. At the lower end of the temperature scale (below $750{ }^{\circ} \mathrm{C}$ ), there is a decreasing trend in non-condensable gas yield with increasing stage of maturity (Fig. 5). This is probably due to slow evolution at this temperature of the strong bonds associated with the extra lignin gained at maturity and intended for cell wall structural rigidity. But at 900 and 


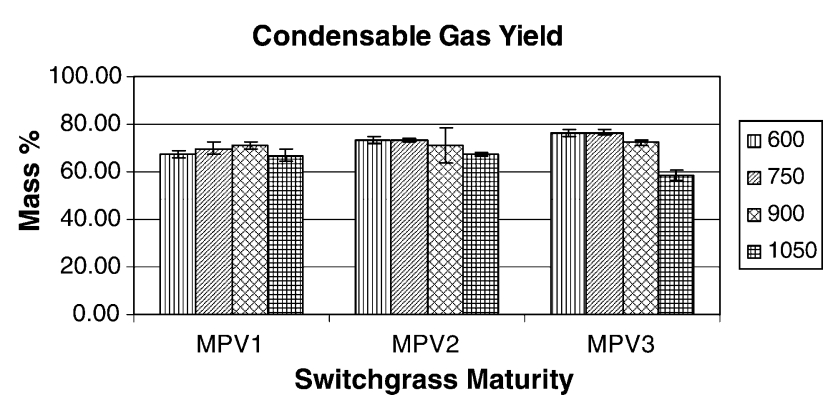

Fig. 4. Condensable gas including $\mathrm{C}_{4} / \mathrm{H}_{2} \mathrm{O} /$ tar yield grouped with switchgrass maturity and pyrolysis temperature.

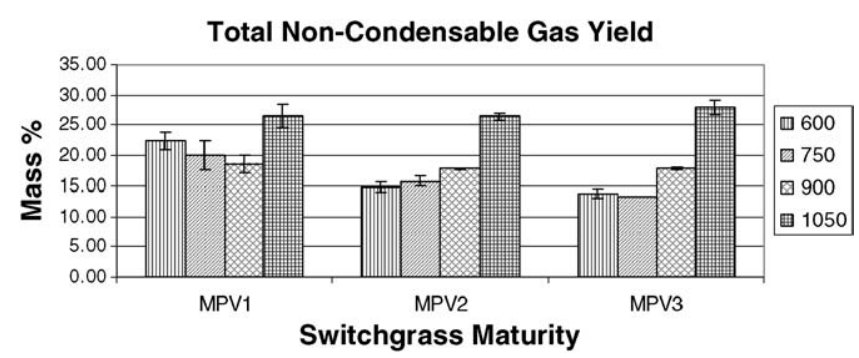

Fig. 5. Total non-condensable gas yield as function of forage sample maturity and pyrolysis temperature. Switchgrass physiological maturity increased from MPV1 to MPV3.

$1050{ }^{\circ} \mathrm{C}$, yields are relatively constant at all three maturity levels. Evidence of this lies in the declining of $\mathrm{CO}_{2}$ yield (Fig. 6), the absence of and the declining evolution trends for some of the hydrocarbon gases particularly $\mathrm{CH}_{4}$, and $\mathrm{C}_{3} \mathrm{H}_{8}$ (Fig. 7). At higher temperatures, however, the effect of maturity on the release rates has diminished or is only marginal because no extent of structural bond
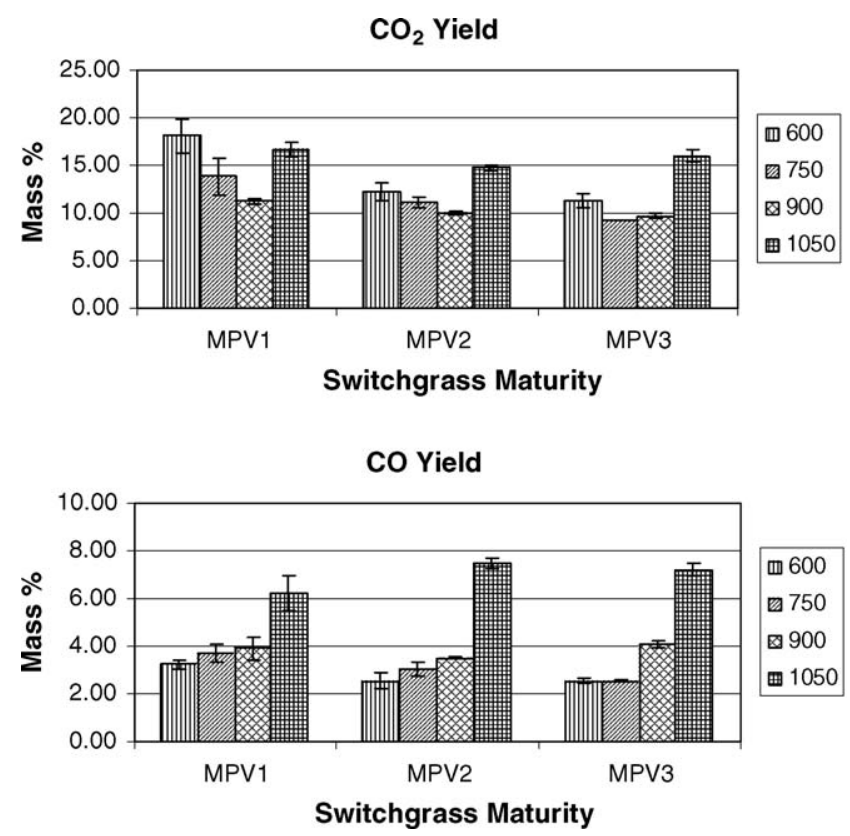

Fig. 6. $\mathrm{CO}_{2}$ and $\mathrm{CO}$ yields as function of forage maturity and pyrolysis temperature.
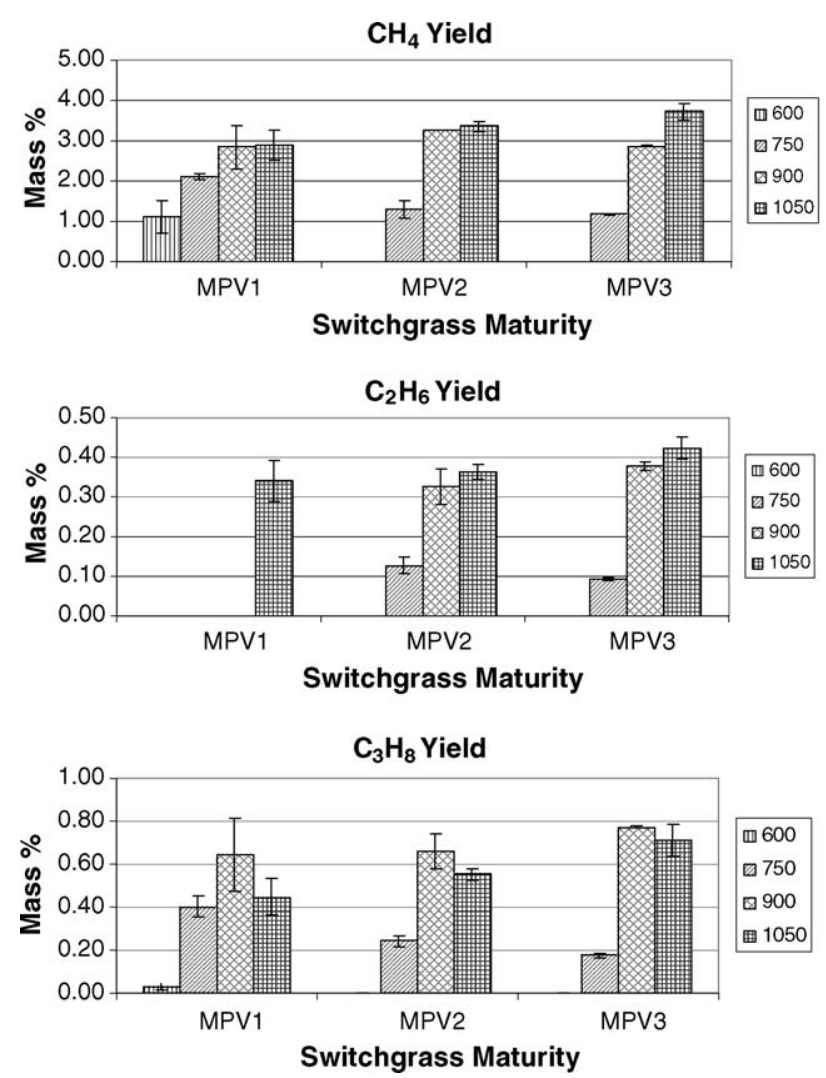

Fig. 7. Light hydrocarbon gas yield grouped with switchgrass maturity and pyrolysis temperature.

strengthening at the maturity stage could withstand the thermal degradation.

\subsection{Heat of combustion}

The pyrolysis reactions result in a syngas whose quality is dependent on pyrolysis temperature and in part by plant maturity. Although we did not measure hydrogen separately, we believe that modest conclusions can still be made about of the heat of combustion of the gas produced. Fig. 8 shows the heat content of the non-condensable gas calculated based on the weight fractions of the components we measured. As is seen here, the value peaks at the $900{ }^{\circ} \mathrm{C}$ temperature boundary. At this temperature, the non-condensable gases from both mature grass samples, MPV2 and MPV3, have almost the same energy content of about $3500 \mathrm{kcal} / \mathrm{kg}$, which is higher than the MPV1 sample at $3000 \mathrm{kcal} / \mathrm{kg}$. Considering the fact that if burned "as is" switchgrass has a gross energy content of $4398 \mathrm{kcal} / \mathrm{kg}$ on dry basis [10] then the quality of the non-condensable gas at $900{ }^{\circ} \mathrm{C}$ pyrolysis constitutes about $68 \%$ of this amount at boot and $80 \%$ at senescent. This, in addition to the fact that there is still over $50 \%$ of the biomass weight available as condensable gas (which can be recovered as pyrolytic oil) and about $10 \%$ char (another energy source), makes thermochemical conversion of this energy crop even more plausible. 


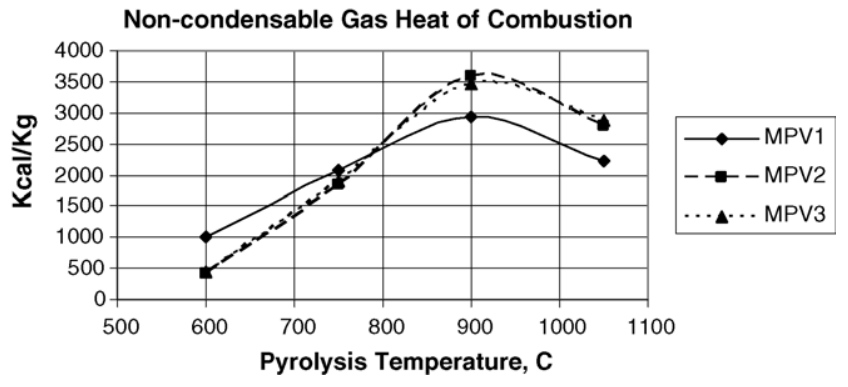

Fig. 8. Heat of combustion of non-condensable gas.

\subsection{Char morphology}

In Fig. 9, we show SEM photomicrographs of char remaining after exposing the sample in the pyrolyzer for $20 \mathrm{~s}$ at 600 and $750{ }^{\circ} \mathrm{C}$. Since the biomass sample comprised whole herbage, it is difficult to tell which physiological portion of the plant this char sample represents. This notwithstanding, its morphology, in particular the pore structure and volume, including their development are important to the ultimate use of switchgrass as an energy crop because the porous char can in itself constitute a valuable byproduct. More characterization of the residual char structure is underway.

\subsection{Decomposition kinetics}

At the temperature range we studied $\left(600-1050{ }^{\circ} \mathrm{C}\right)$, the evolution rates for the pyrolysis of switchgrass mimic secondary and tertiary reaction patterns described for lignin more than for cellulose and hemicellulose indicating that within the study, conditions lignin decomposition might have been the rate controlling factor. However, instead of following the decomposition of each chemical component, i.e. cellulose, hemicellulose and lignin into various gases as described by Avni et al. [25], we represented the entire biomass material to decompose to yield individual gases that we calibrated. The kinetics of the evolution we employed follows the generalized equation:

$\frac{\mathrm{d} m}{\mathrm{~d} t}=A_{\mathrm{o}} \exp \left(-\frac{E_{m}}{R T}\right)\left(m_{\mathrm{f}}-m\right)^{n}$,

where $m$ is the yield of any product of the gases quantified (i.e. $\mathrm{CO}_{2}, \mathrm{CO}, \mathrm{CH}_{4}, \mathrm{C}_{2} \mathrm{H}_{6}, \mathrm{C}_{2} \mathrm{H}_{4}, \mathrm{C}_{3} \mathrm{H}_{8}$ or their sum); $A_{\mathrm{o}}$ is the frequency factor corresponding to product $m,(1 / \mathrm{s}) ; E_{m}$ is the activation energy corresponding to product $m(\mathrm{~J} / \mathrm{mol}) ; R$ is the universal gas constant $(8.314 \mathrm{~J} / \mathrm{mol} \mathrm{K}) ; m_{\mathrm{f}}$ is the final yield of product " $m$ " (after $20 \mathrm{~s}$ ); $T$ is the temperature in Kelvin (i.e., 873, 1023, 1173 and $1323 \mathrm{~K}$ ).

Unlike most biomass pyrolysis kinetics reported in the literature we assumed the decomposition of switchgrass to follow multiple order reaction kinetics following Milosavljevic and Suuberg [27]. They have shown that at temperatures greater than $600 \mathrm{~K}$, biomass decomposition does not fit first order reaction kinetics because the Arrhenius-type plots of the rate constant and temperature do not always conform to linear relationships. In view of this, we carried out a three parameter estimation of the activation energy, $E$, the pre-exponential factor, $A_{\mathrm{o}}$ and the reaction order, $n$, by calculating the least-square errors and fitting the experimental data to the differential equation with the multivariable parameter estimation model in MATLAB. While there was a fit between model and experiments, the activation energies and the frequency factors estimated with the three parameter estimation were unrealistic. There was an order of magnitude differences between the values for
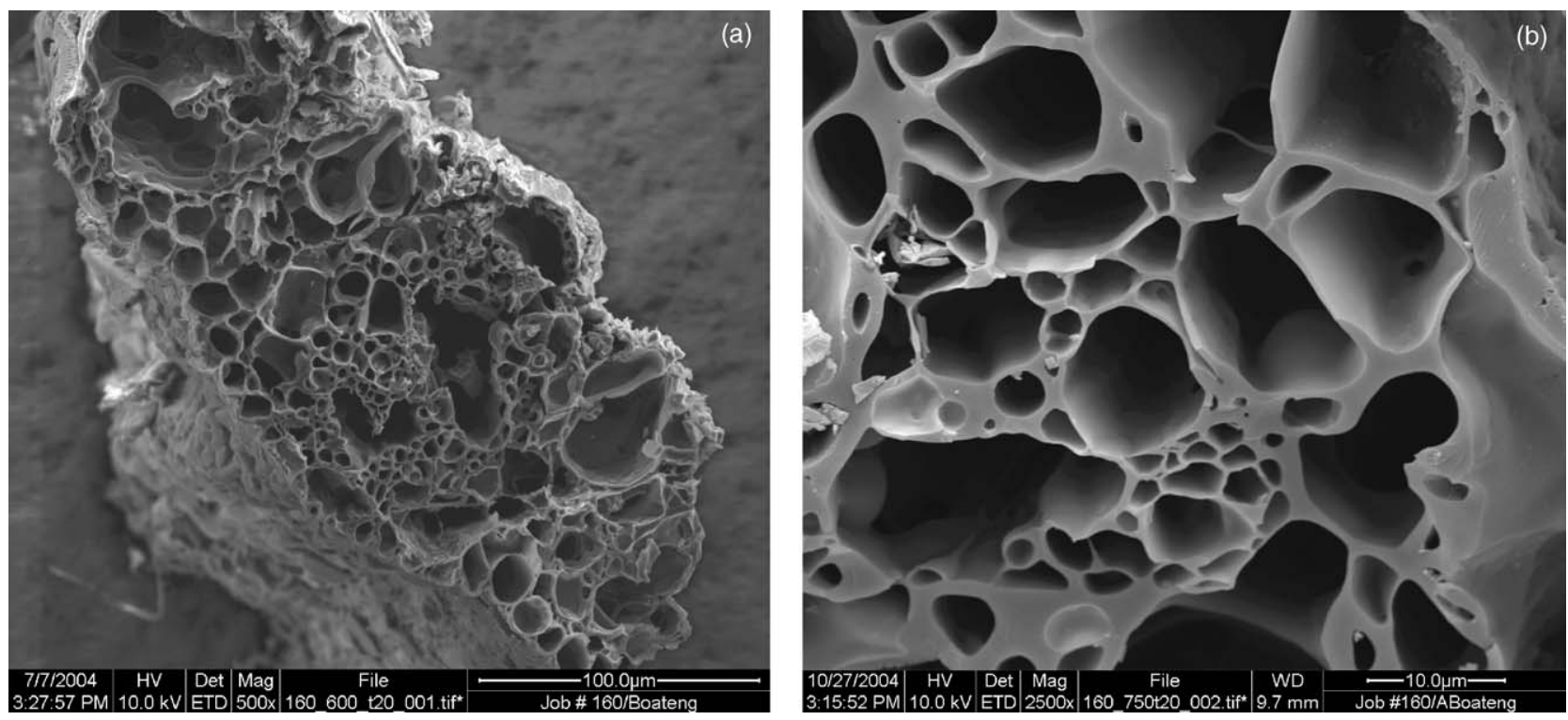

Fig. 9. (a) SEM photomicrograph of MPV1 (boot) switchgrass char remaining after $20 \mathrm{~s}$ in the pyrolyzer at $600{ }^{\circ} \mathrm{C}$; (b) SEM photomicrograph of MPV1 (boot) switchgrass char remaining after $20 \mathrm{~s}$ in the pyrolyzer at $750{ }^{\circ} \mathrm{C}$. 
Table 2

First order reaction rate kinetic constants established using parameter estimation model

\begin{tabular}{lrr}
\hline & $A(1 / \mathrm{s})$ & $E(\mathrm{~J} / \mathrm{mol})$ \\
\hline $\mathrm{MPV} 1$ & & \\
$\mathrm{CO}$ & 1.2296 & 1613.80 \\
$\mathrm{CO}_{2}$ & 1.2940 & 165.87 \\
$\mathrm{C}_{3} \mathrm{H}_{8}$ & 0.9665 & 5937.05 \\
Total non-condensable gas & 1.8336 & 6971.34 \\
$\mathrm{MPV} 2$ & & \\
$\mathrm{CO}$ & 1.1629 & 1958.35 \\
$\mathrm{CO}$ & 1.3052 & 100.00 \\
$\mathrm{CH}_{4}$ & 0.9100 & 4777.26 \\
$\mathrm{C}_{3} \mathrm{H}_{8}$ & 0.8940 & 4350.30 \\
$\mathrm{Total}_{4}$ non-condensable gas & 4.1052 & 11887.32 \\
$\mathrm{MPV}$ & & \\
$\mathrm{CO}$ & 0.5698 & 2106.43 \\
$\mathrm{CO}_{2}$ & 0.8577 & 262.72 \\
$\mathrm{CH}_{4}$ & 0.6707 & 2739.20 \\
Total non-condensable gas & 3.9726 & 16170.43 \\
\hline
\end{tabular}

switchgrass at the different maturity stages. While we expected plant maturity would have some effect, the wide disparity in $A$ and $E$ which resulted cast doubt on the applicability of the model. In order to establish a better relationship between grass maturity and activation energy, we resolved to a two-parameter estimation model by assuming first order reaction kinetics, e.g. Caballero et al. [16], Garcia et al. [28] and Funazukuri et al. [29]. The calculated frequency factor and the activation energies for some non-condensable gases and their sum are shown in Table 2. The frequency factor for the gases ranged between 0.55 and $3.97 \mathrm{~s}^{-1}$. This narrow range allowed fair comparison of the activation energies for the samples from the three maturity stages. The values calculated for the decomposition of the non-condensable gas were $6971 \mathrm{~J} / \mathrm{mol}$ at E1 maturity, $11,887 \mathrm{~J} / \mathrm{mol}$ at R4 maturity and 16,170 J/ $\mathrm{mol}$ at S5. This shows a linear increase in activation energy for the switchgrass samples from the pre-boot vegetative stage to post-frost senescent stage (Fig. 10) and is consistent with the increased lignin concentration of the samples which is typical of perennial grass cell walls as they mature. Although higher activation energies of the order of 47$56 \mathrm{kcal} / \mathrm{mol}$ have been reported for cellulose [4] they were estimated using one-parameter estimation with a fixed

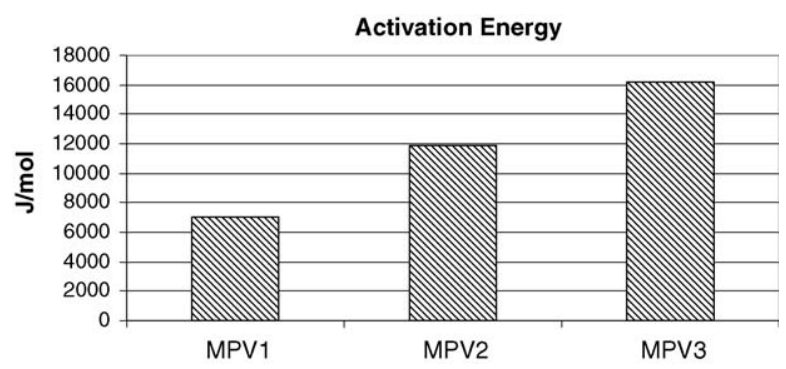

Fig. 10. Estimated first order activation energy as function of switchgrass maturity.
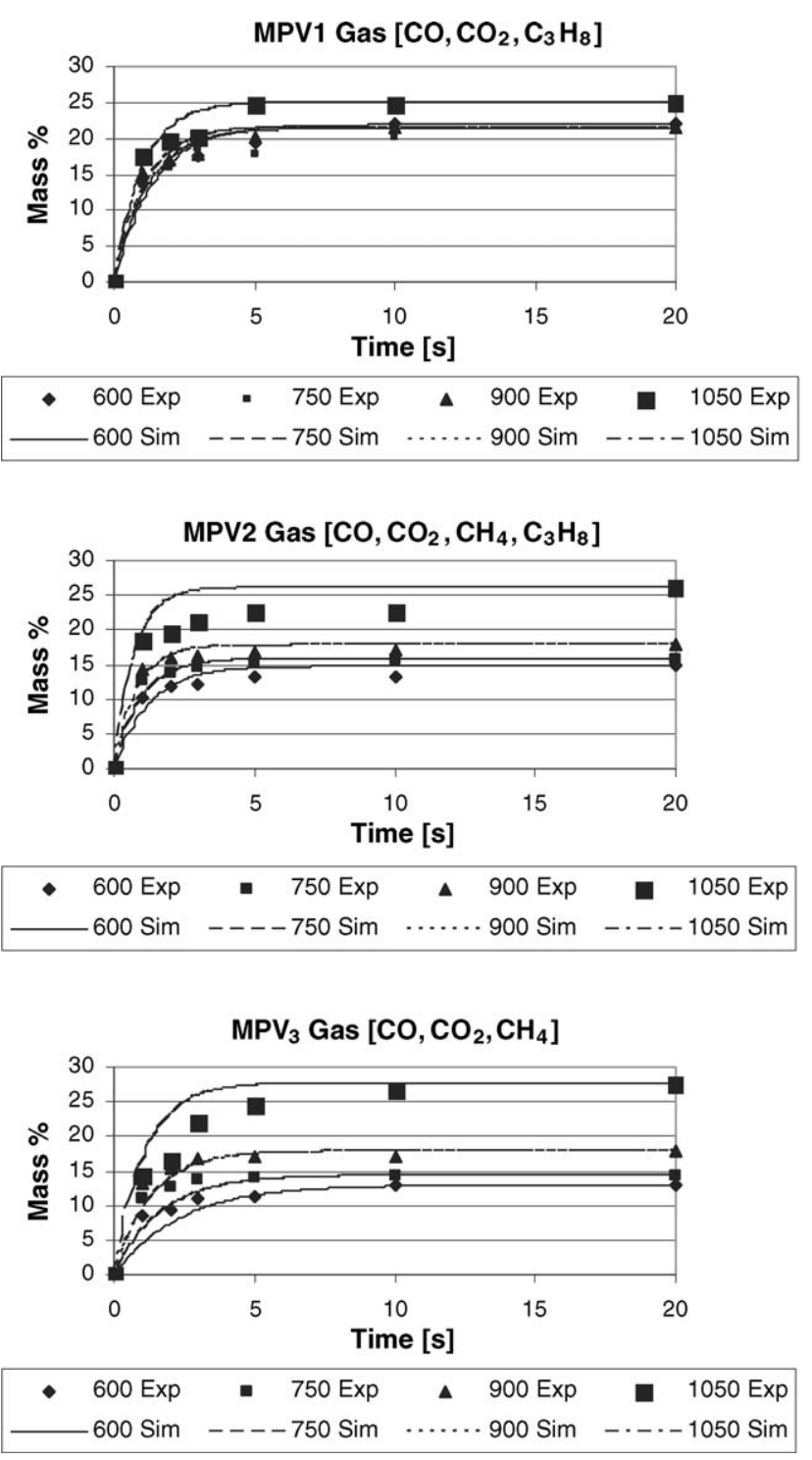

Fig. 11. Time resolved evolution of total non-condensable gas quantified from the pyrolysis of switchgrass harvested at boot, mature and frost, respectively.

frequency factor. Using a two-parameter estimation similar to the current study, Caballero et al. [16] reported activation energies in the order of 8-9 kcal/mol and frequency factor of $59 \mathrm{~s}^{-1}$ for lignin. Garcia et al. [28] have also reported $E=8.7 \mathrm{~kJ} / \mathrm{mol}$ and $A_{\mathrm{o}}=5.8 \mathrm{~s}^{-1}$ for municipal solid waste. These figures are comparable with that obtained in the present study although the biomass is different. It is worth mentioning that for biomass substrates such as cellulose, the correlation between high temperature and low activation energy has been rationalized by others [27].

The activation energies for $\mathrm{CO}_{2}$ were uncharacteristically low. However, this may be attributed to either loose $\mathrm{C}-\mathrm{O}$ bonds associated with the decomposition of aldehydic groups in the evolved tar at higher temperatures or simply to the fact that it does not fit the Arrhenius representation. Fisher et al. [22] found similar low activation energies and 
pre-exponential factors corresponding to a reaction order of 2 with their TGA data on cellulose, xylan and pectin studied under similar temperature conditions although they thought their values were underestimated. But Milosavljevic and Suuberg [27] had earlier pointed out the possibility of encountering low activation energies at elevated pyrolysis temperatures. The temperature effect on changes in activation energy has also been reported previously for grain pyrolysis [30]. The temporal events of the evolution of various gases quantified for $600-1050{ }^{\circ} \mathrm{C}$ temperature range are presented in Fig. 11 for the total non-condensable gas. There appears to be a good fit between the calculated and experimental yield values. Overall, the rate constant for the total gas that we quantified increased with increased maturity irrespective of the minor differences in the preexponential factor.

\section{Conclusions}

The thermochemical platform is a viable option for the conversion of switchgrass, a perennial herbaceous plant, into gaseous and liquid fuels. It has been demonstrated here that plant maturity determined by the time of harvest may play an important role in the pyrolysis of switchgrass. To maximize the yield and also the quality (heat of combustion) of the non-condensable gas, allowing the plant cell walls to mature by harvesting late and pyrolyzing at about $900{ }^{\circ} \mathrm{C}$ may be beneficial (Fig. 8). To maximize condensable gases (which can be refined to pyrolytic oils and chemicals), higher maturity may also be beneficial, especially when coupled to pyrolysis temperatures lower than $900{ }^{\circ} \mathrm{C}$ (Fig. 4). At the temperatures studied, $600-1050{ }^{\circ} \mathrm{C}$ secondary pyrolysis reaction dominated the pyrolysis reaction kinetics. There was a linear increase in activation energy for gas decomposition from the vegetative or pre-boot to senescent stages of maturity consistent with lignin growth associated with cell wall development as plant matures.

It is important to note that the samples analyzed in this study represent single samples collected from one location at three different stages of physiological maturity. The conclusions drawn are valid for these particular samples and other similar samples Additional research using switchgrass samples from multi-year and multi-location studies with defined agronomic and genetic characteristics is in progress to determine the effects of management, genetics and environmental effects on switchgrass composition and pyrolysis products.

\section{Acknowledgements}

The authors wish to acknowledge Mr. Brett Newswanger, a 2004 summer student from Columbia University, Dr. Peter Cooke, Dr. Alberto Nunez and Mr. Rich Cook of ERRC for technical assistance and Dr. Hans Joachim Jung of ARS
Plant Science Research Unit in St. Paul Minnesota for providing chemical analysis of test samples.

\section{References}

[1] M.J. Realff, C. Abbas, J. Ind. Ecol. 7 (2004) 5.

[2] A. McAloon, personal communication (2004).

[3] T.A. Milne, C.C. Elam, R.J. Evans, Hydrogen from Biomass. State of the Art and Research Challenges. NREL Report IEA/H2/TR-02/001. Prepared for the Int'1 Energy Agency Agreement of the Production and Utilization of Hydrogen, Task 16, Hydrogen from Carbon-Containing Materials, 2002.

[4] M.J. Antal Jr., G. Varhegyi, Ind. Eng. Chem. Res. 34 (1995) 703.

[5] P. McKendry, Bioresource Technol. 83 (2002) 47.

[6] M.J. Antal Jr., G. Varhegyi, E. Jacob, Ind. Eng. Chem. Res. 37 (1998) 1267.

[7] G.R. Jackson, D. Mahajan, U.S. Patent No. 6,248,796 (2001).

[8] W. Curtis, C. Ferland, J. McKissick, W. Barnes, University of Georgia Report http://www.agecon.uga.edu/ caed/FeasibilityStudy603.pdf (2003).

[9] D.G. Urgate, D.L. Torre, M.E. Walsh, H. Shapouri, S.P. Slinsky, The Economic Impacts of Bioenergy Crop Production on U.S. Agriculture, Agricultural Economic Report, No. 816, USDA (2003).

[10] S. McLaughlin, J. Bouton, D. Bransby, B. Conger, W. Ocumpaugh, D. Parrish, C. Taliaferro, K. Vogel, S. Wullschleger, in: J. Janick (Ed.), ASHS Press, Alexandria, VA, 1999, p. 282.

[11] S.B. McLaughlin, D.G. De La Torre Ugarte, Jr., C.T. Garten, L.R. Lynd, M.A. Sanderson, in: V.R. Tolbert, D.D. Wolf (Eds.), High-value Renewable Energy from Prairie Grasses, Environ. Sci. Technol. 36 (2002) 2122-2129.

[12] S.B. McLaughlin, L.A. Kszos, Biomass Bioenergy 28 (6) (2005) 515 535.

[13] K.P. Vogel, Switchgrass, in: L.E. Moser, L. Sollenberger, B. Burson (Eds.), Warm-season $\left(\mathrm{C}_{4}\right)$ Grasses, ASA-CSSA-SSSA Monograph, Madison, WI, 2004, pp. 561-588.

[14] B.S. Dien, H.G. Jung, K.P. Vogel, M.D. Casler, J.F.S. Lamb, P.J. Weimer, L. Iten, R.B. Mitchell, G. Sarath, Chemical composition and response to dilute-acid pretreatment and enzymatic saccharification of alfalfa, reed canarygrass, and switchgrass, Biomass Bioenergy, 2005, submitted.

[15] K.J. Moore, L.E. Moser, K.P. Vogel, S.S. Waller, B.E. Johnson, J.F. Pedersen, Agron. J. 83 (6) (1991) 1073.

[16] J.A. Caballero, R. Font, A. Marcilla, A.N. Garcia, J. Anal. Appl. Pyrolysis 27 (1993) 221.

[17] M. Nali, F. Corana, L. Montanari, L. Pellegrini, J. Anal. Appl. Pyrolysis 29 (1994) 15.

[18] T.P. Wampler, CDS Analytical, personal communications (2005).

[19] M.A. Sanderson, D.D. Wolf, Agron. J. 88 (1996) 908.

[20] H. Teng, Y.-C. Wei, Ind. Eng. Chem. Res. 37 (1998) 3806.

[21] C. Fushimi, K. Araki, Y. Yamaguchi, A. Tsutsumi, Ind. Eng. Chem. Res. 42 (2003) 3929.

[22] T. Fisher, M. Hajaligol, B. Waymack, D. Kellogg, J. Anal. Appl. Pyrolysis 62 (2002) 331

[23] C. Di Blasi, G. Signorelli, G. Portoricco, Ind. Eng. Chem. Res. 38 (1999) 2571.

[24] W.P. Walawender, personal communications (2004).

[25] E. Avni, R.W. Coughlin, P.R. Solomon, H.H. King, Fuel 64 (1985) 1495 .

[26] J. Ralph, R.D. Hatfield, J. Agric. Food Chem. 39 (1991) 1426.

[27] I. Milosavljevic, E.M. Suuberg, Ind. Eng. Chem. Res. 34 (1995) 1081.

[28] A.N. Garcia, R. Font, A. Marcilla, J. Anal. Appl. Pyrolysis 23 (1992) 99.

[29] T. Funazukuri, R.R. Hudgins, P.L. Silveston, J. Anal. Appl. Pyrolysis 10 (1987) 225.

[30] A.A. Boateng, L.T. Fan, W.P. Walawender, C.S. Chee, S.M. Chern, Chem. Eng. Commun. 113 (1992) 117. 